\title{
The effect of mango waste meal in the protein:carbohydrate ratio on performance and body composition of pacamã fish (Lophiosilurus alexandri)
}

\author{
[Efeito do farelo residual da manga na relação proteína:carboidrato sobre o desempenho e \\ a composição corporal do pacamã Lophiosilurus alexandri] \\ A.M. Souza ${ }^{1}$, J.F.B. Melo ${ }^{2}$, E.M.S. Moreira ${ }^{3}$, E.M. Souza ${ }^{4}$ \\ ${ }^{1}$ Universidade Federal da Bahia - UFBA - Salvador, BA \\ ${ }^{2}$ Universidade Federal do Vale do São Francisco - UNIVASF - Petrolina, PE \\ ${ }^{3}$ Universidade Federal Rural de Pernambuco - UFRPE - Recife, PE \\ ${ }^{4}$ Instituto Federal de Educação Ciência e Tecnologia do Sertão Pernambucano - IFSERTÃO - Campus Ouricuri, PE
}

\begin{abstract}
Avaliou-se a inclusão do farelo residual de manga sem casca como fonte de carboidrato na relação proteína:carboidrato (PB:CHO) sobre o desempenho e a composição química da carcaça em juvenis de pacamãs. Foram utilizados 150 peixes $(11,31 \pm 0,96 \mathrm{~g})$ estocados em 16 caixas de $500 \mathrm{~L}$, alimentados três vezes ao dia (10\% peso vivo), em um sistema de recirculação de água com biofiltro. Os tratamentos consistiram em quatro dietas experimentais com níveis decrescentes da relação entre proteína bruta e carboidrato $(1,40 ; 0,94 ; 0,56$ e 0,29$)$, com quatro repetições cada tratamento. Ao final de 60 dias, foram avaliados o desempenho zootécnico (ganho de peso médio final, taxa de crescimento específico, consumo total de ração aparente, conversão alimentar aparente, rendimento de carcaça, sobrevivência) e a composição físico-química da carcaça. As relações de proteína:carboidrato afetaram todas as variáveis de desempenho $(\mathrm{P}<0,05)$, com exceção da sobrevivência $(\mathrm{P}>0,05)$. Os valores da composição química da carcaça foram alterados, com exceção da matéria mineral, do $\mathrm{pH}$ e da umidade. A farinha de manga pode ser utilizada na proporção de até $15 \%$ na ração de pacamã, estabelecendo uma relação 1,40 PB:CHO, sem prejudicar o desempenho zootécnico e a composição química da carcaça.
\end{abstract}

Palavras-chave: nutrição, inclusão, carcaça

\section{RESUMO}

We evaluated the inclusion of peeled-mango waste meal as a source of carbohydrate in the protein:carbohydrate ratio $(\mathrm{CP}: \mathrm{CH})$ on performance and chemical composition of pacama (Lophiosilurus alexandri) juveniles. One hundred and fifty fish $(11.31 \pm 0.96 \mathrm{~g})$ were stocked in sixteen 500 L tanks, fed three times daily (10\% of live weight), in a system with water recirculation with biofilter. The treatments consisted of four experimental diets with decreasing levels of the ratio between crude protein and carbohydrate $(1.40,0.94,0.56$ and 0.29), with four replications per treatment. At the end of 60 days, we evaluated animal performance (final average weight gain, specific growth rate, total apparent feed intake, carcass yield, survival) and physicochemical composition of the carcass. The protein:carbohydrate ratios affected all performance variables $(P<0.05)$, except for survival $(P>0.05)$. The carcass chemical composition variables were modified, except for mineral matter, $\mathrm{pH}$ and moisture. Mango meal can be used at the proportion of up to $15 \%$ in the diet for pacamã, establishing a CP:CHO ratio of 1.40 without impairing animal performance and the carcass chemical composition.

Keywords: nutrition, inclusion, carcass

Recebido em 26 de agosto de 2013

Aceito em 9 de janeiro de 2015

E-mail: anderson_zootecnia@yahoo.com.br 


\section{INTRODUCTION}

Mango is cultivated in several regions of Brazil, especially in the northeast, because it presents excellent conditions for its development and production, especially in the Vale do São Francisco region. The mango fruit is widely available in this region, with a large volume of exports: in 2010, 108.38 thousand tons were exported, representing $90 \%$ of all national production (Coelho, 2002).

In Brazil, the deficiency of modern and appropriate techniques in handling, transportation and stocking of fruits, associated with the high perishability and lack of trained staff and infrastructure for their processing and preservation, have generated a loss of around $30 \%$ of the production, and in some cases it exceeds 50\% (Argaiz et al., 1993), and often they are disposed of in the environment with no previous treatment, causing significant economic damages, in addition to environmental problems. However, fruits unsuitable for human consumption have nutritive potential and can be used as a source of carbohydrates in the formulation of diets for fish.

According to Monteiro (2009), mango contains 10.97 to $14.36 \mathrm{~g} / 100 \mathrm{~g}$ carbohydrates; 11.77 to $22.5 \mathrm{mg} / 100 \mathrm{~g}$ vitamin $\mathrm{C}$; and an energy content of 50.02 to $58.12 \mathrm{kcal}$ in $\mathrm{g} / 100 \mathrm{~g}$ in its pulp and skin, respectively. Utilizing mango waste meal to feed Nile tilapia at 0, 5, 10 and $15 \%$, Lima et al. (2011) did not observe differences in their performance and also in the apparent digestibility coefficients of dry matter, crude protein and gross energy, which enabled the inclusion of up to $15 \%$ of the mango waste meal in diets for tilapia.

To intensify production, it is necessary to introduce technology in fish management, especially utilizing balanced diets. Thus, it is essential that we conduct studies on nutrition that contribute to the production of species-specific diets. According to Kaushik (1989), the expenses with feeding in fish farming account for up to $70 \%$ of the total production costs, so the use of effective diet-processing techniques and application of appropriate feeding strategies are paramount to reducing the final cost (Kubitza,1998).
According to Andriguetto et al. (1985), the fact that protein is the most important macronutrient for the growth and the most expensive ingredient in diets leads scientific research to seek the lowest amount of this ingredient that the organism needs in order to reciprocate with better production, and because carbohydrate is the ingredient with the lowest cost in the formulation of diets (Silveira et al., 2010), it is necessary to know the ideal proportions of these components, in diet formulation, so as to maximize the profitability of intensive fish farming.

The species utilized in this study was pacamã (Lophiosilurus alexandri), a fish of the family Pseudopimelodidae (order Siluriformes), native to the São Francisco river basin. This fish is highly marketable because its meat is devoid of intramuscular spine, and its taste is highly appreciated by the consumers. It is a carnivore species and has sedentary behavior, with multiple spawning and preference for lentic environments in sandy or stony areas (Shibata, 2003).

Given the importance of determining the ratio between protein and carbohydrate in diets for fish, along with the marketability and performance potential of this species for intensive fish farming in the semi-arid region, the aim of this study was to determine the ideal proportion between protein and carbohydrate in the feeding of pacamã juveniles using mango waste meal as source of carbohydrate, evaluating animal performance and physicochemical carcass composition under different diets, thereby proposing the ideal protein level in the composition of their diet.

\section{MATERIAL AND METHODS}

The experiment was conducted in the facilities of the Laboratory of Aquiculture of Campus Ciências Agrárias of Universidade Federal do Vale do São Francisco, during 60 days. One hundred and fifty pacamã juveniles from Companhia de Desenvolvimento dos Vales do São Francisco e do Parnaíba - CODEVASF-PE were utilized. The fish were housed at a density of seven fish per tank, with initial live weight (ILW) of $11.31 \pm 0.96 \mathrm{~g}$. They were distributed into 16 circular polyethylene water tanks $(500 \mathrm{~L})$ in a water recirculation system with mechanic 
and biological filters. The animals went through an acclimation period of seven days, fed a diet formulated to have $40 \%$ crude protein and $3,000 \mathrm{kcal}$ gross energy (National..., 2011). Mango waste meal was used as the carbohydrate source at the proportion of $25 \%$.

The water temperature, $\mathrm{pH}$, dissolved oxygen and electrical conductivity were measured; the latter was measured with the Hanna Oxy-chek portable device. The experimental units were siphoned in the morning and afternoon, before feeding, with exchange of approximately $10 \%$ of the total water so as to remove feces and feed leftovers.

The experimental design was entirely random, with four treatments and four replications. The data were subjected to variance analysis, and the test of means used were Tukey's. The treatments consisted of four experimental diets with decreasing levels of the ratio between crude protein and carbohydrate (CP:CH - 1.40, 0.94, 0.56 and 0.29). The $\mathrm{CP}: \mathrm{CH}$ ratios were calculated based on the proportion of nitrogenfree extracts (NFE) over the proportion of crude protein $(\mathrm{CP})$.

Table 1. Chemical and calculated composition of the experimental diets

\begin{tabular}{|c|c|c|c|c|}
\hline \multirow{2}{*}{ INGREDIENTS } & \multicolumn{4}{|c|}{$\mathrm{CP}: \mathrm{CH}$ ratios } \\
\hline & 1.40 & 0.94 & 0.56 & 0.29 \\
\hline Fish meal & 64.1 & 51.6 & 39.1 & 26.6 \\
\hline Soybean meal & 10 & 7.5 & 5 & 2.5 \\
\hline Mango meal & 15 & 30 & 45 & 60 \\
\hline Dicalcium phosphate & 0.84 & 0.84 & 0.84 & 0.84 \\
\hline Soybean oil & 8 & 8 & 8 & 8 \\
\hline Min. and vit. $\operatorname{mix}^{1}$ & 2 & 2 & 2 & 2 \\
\hline Vitamin $C^{2}$ & 0.05 & 0.05 & 0.05 & 0.05 \\
\hline $\mathrm{BHT}^{3}$ & 0.01 & 0.01 & 0.01 & 0.01 \\
\hline Total $(\%)$ & 100 & 100 & 100 & 100 \\
\hline \multicolumn{5}{|c|}{ Calculated values $^{4}$} \\
\hline $\mathrm{CP}(\%)$ & 40.16 & 34.40 & 25.63 & 16,24 \\
\hline $\operatorname{NFE}(\%)$ & 28.68 & 36.63 & 46.01 & 56,33 \\
\hline GE:CP (Kcal. g $\left.{ }^{-1}\right)$ & 10.61 & 12.37 & 16.57 & 35.83 \\
\hline $\mathrm{GE}(\mathrm{Kcal} / \mathrm{kg})$ & 4263 & 4255 & 4248 & 5826 \\
\hline $\mathrm{EE}(\%)$ & 16.03 & 15.26 & 14.17 & 12.58 \\
\hline $\mathrm{CF}(\%)$ & 1.78 & 1.99 & 2.19 & 2.40 \\
\hline MM (\%) & 10.81 & 8.27 & 8.26 & 6.35 \\
\hline $\mathrm{OM}(\%)$ & 2.54 & 3.45 & 3.74 & 6.08 \\
\hline DM (\%) & 97.46 & 96.55 & 96.26 & 93.22 \\
\hline
\end{tabular}

1. Min. and vit. mix (Supremais, Campinas/SP, Brazil): Composition per kg: vit. A =1,200,000 IU; vit. D3 = 200,000 $\mathrm{IU}$; vit. $\mathrm{E}=12,000 \mathrm{mg}$; vit. $\mathrm{K} 3=2,400 \mathrm{mg}$; vit. B1 = 4,800mg; vit. $\mathrm{B} 2=4,800 \mathrm{mg}$; vit. $\mathrm{B} 6=4,000 \mathrm{mg}$; vit. $\mathrm{B} 12=$ 4,800mg; folicacid $=1,200 \mathrm{mg}$; calciumpantothenate $=12,000 \mathrm{mg}$; biotin $=48 \mathrm{mg}$; choline $=65,000 \mathrm{mg}$; nicotinicacid $=$ $24,000 \mathrm{mg} ; \mathrm{Fe}=10,000 \mathrm{~g} ; \mathrm{Cu}=600 \mathrm{mg} ; \mathrm{Mn}=4,000 \mathrm{mg} ; \mathrm{Zn}=6,000 \mathrm{mg} ; \mathrm{I}=20 \mathrm{mg} ; \mathrm{Co}=2 \mathrm{mg}$; and $\mathrm{Se}=20 \mathrm{mg}$.

2. Vit. C (Basf, São Paulo/SP, Brazil): calcium salt, ascorbic acid-2-monophosphate, $42 \%$ active ingredient.

3. Butylatedhydroxytoluene.

4. $\mathrm{CP}=$ crude protein; $\mathrm{NFE}=$ nitrogen=free extract; $\mathrm{GE}: \mathrm{CP}=$ gross energy:crude protein ratio; $\mathrm{GE}=$ gross energy; $\mathrm{EE}=$ ether extract; $\mathrm{CF}=$ crude fiber; $\mathrm{MM}=$ mineral matter; $\mathrm{OM}=$ organic matter; $\mathrm{DM}=$ dry matter; $\mathrm{CP}: \mathrm{CH}=\mathrm{crude}$ protein:carbohydrate ratio.

To produce the mango waste meal we utilized ripe mangos from the Tommy Atkins variety, originating from discarded fruits from Centro de Abastecimento e Logística da Bahia - CEASA$\mathrm{BA}$, located in the city of Juazeiro/BA, Brazil. The fruits were washed, peeled, cut in small pieces and had their seeds removed. Afterwards, they were dried in a forced-ventilation oven at $55^{\circ} \mathrm{C}$ for 86 hours. Subsequently, they were ground in knife mills with $1 \mathrm{~mm}$ sieves and stored in a freezer at $-18^{\circ} \mathrm{C}$. All diet ingredients were ground in a knife mill with $0.5 \mathrm{~mm}$ sieve, and then gathered until the mixture appeared homogeneous. To pelletize the diets, the mixture 
of ingredients was moistened with water at $50^{\circ} \mathrm{C}$ and then the diets were processed in a meat grinder and dried in a forced-ventilation oven at $65^{\circ} \mathrm{C}$ for about 24 hours. The pellets were broken with the aid of a manual mill, and separated into different diameters in sieves of different pores to have appropriate sizes for the mouths of the animals according to their growth.

The fish were fed three times daily, at $08 \mathrm{~h} 00$, $12 \mathrm{~h} 00$ and $17 \mathrm{~h} 00$. The amount of feed supplied daily was $10 \%$ of the body weight, which was corrected every 15 days, when biometry was performed. Four biometric analyses were performed, totaling 60 days of feeding. The productive performance of the pacamã juveniles in each experimental plot was analyzed by the final average weight gain (FAWG), specific growth rate (SGR), carcass yield (CY), total apparent feed intake (TAFI), apparent feed conversion (AFC) and survival (S).

At the end of the experimental period all animals were weighed to measure the growth data, and subsequently stunned with water and ice. The fish were sacrificed by medullar section, a procedure approved by the Ethics Committee on Human and Animal Studies (CEEHA UNIVASF, protocol no. 0022/26091).

The analysis of the body composition of fish was performed by dehydrating the carcasses in a forced-ventilation oven $\left(55^{\circ} \mathrm{C}\right)$ for 72 hours and grinding them according to the technique described by the AOAC (Official..., 1990), shown in Tab. 1. Moisture (M) was determined with the method based on the evaporation of the water present in the sample in a vacuum-oven at $70^{\circ} \mathrm{C}$ and $660 \mathrm{mmHg}$ until constant weight. Crude protein $(\mathrm{CP})$ was determined by the Kjeldahl method to determine the total nitrogen. This method is based on the nitrogen content of the organic matter, including the protein nitrogen itself and other non-protein nitrogen compounds such as amines, amino acids, among others. In this case, the result was expressed as crude or total protein, using the 6.25 factor for the calculation. Ether extract (EE) was determined by using chloroform and methanol as solvent. Mineral matter (MM) was determined by incinerating the dry matter in a muffle furnace at $550^{\circ} \mathrm{C}$, until constant weight. To determine the $\mathrm{pH}$, the potentiometric method described in the Lanara manual (Brasil, 1981) was used. Initially, the $\mathrm{pH}$ was measured using a buffer solution $\mathrm{ph}$ 7 at $20{ }^{\circ} \mathrm{C}$. Next, the sample was homogenized with $10 \mathrm{~mL}$ distilled water, and then the electrode of the $\mathrm{pH}$ meter was introduced and reading was performed directly on the sample.

The data were subjected to variance analysis at $5 \%$ of significance. The statistical software Assistat 7.5 beta was used (Silva, 2010).

\section{RESULTS AND DISCUSSION}

Regarding water-quality parameters, the dissolved oxygen levels were $5.4 \pm 1.8$ standard $\mathrm{mg} / \mathrm{L}$, electric conductivity $\mathrm{mS} 0.13 \pm 0.09 ; \mathrm{pH}$ $7.77 \pm 1.8$ and temperature of $26 \pm 3.5^{\circ} \mathrm{C}$. These results are considered acceptable for rearing fish (Boyd, 1990). The mean performance values are described in Tab. 2. All the analyzed variables, except for survival, showed significant differences $(\mathrm{P}<0.05)$.

Table 2. Mean values plus standard deviation of the performance variables and carcass characteristics of pacamã juveniles fed different $\mathrm{CP}: \mathrm{CH}$ ratios

\begin{tabular}{lccccc}
\hline \multirow{2}{*}{ Performance } & \multicolumn{5}{c}{ CP:CH ratios } \\
\cline { 2 - 6 } & 1.40 & $10.45 \pm 1.93$ & $12.11 \pm 2.08$ & $10.27 \pm 2.24$ & 20.72 \\
\hline IWG $(\mathrm{g}) *$ & $12.4 \pm 2.98$ & $17.93 \pm 2.07 \mathrm{~b}$ & $16.32 \pm 1.34 \mathrm{~b}$ & $3.17 \pm 0.84 \mathrm{c}$ & 18.01 \\
FAWG (g) & $46.5 \pm 0.88 \mathrm{a}$ & $0.46 \pm 0.12 \mathrm{~b}$ & $0.39 \pm 0.10 \mathrm{~b}$ & $0.01 \pm 0.04 \mathrm{c}$ & 12.64 \\
SGR (\%/day) & $0.96 \pm 0.11 \mathrm{a}$ & $47.01 \pm 0.94 \mathrm{~b}$ & $54.47 \pm 1.38 \mathrm{~b}$ & $46.19 \pm 1.33 \mathrm{~b}$ & 23.45 \\
TAFI (g) & $78.3 \pm 1.42 \mathrm{a}$ & $2.62 \pm 0.05 \mathrm{~b}$ & $3.34 \pm 0.01 \mathrm{~b}$ & $14.57 \pm 0.02 \mathrm{a}$ & 13.65 \\
AFC & $1.68 \pm 0.03 \mathrm{c}$ & $86.41 \pm 1.14 \mathrm{ab}$ & $83.80 \pm 2.71 \mathrm{~b}$ & $89.58 \pm 2.51 \mathrm{a}$ & 2.33 \\
CY $(\%)$ & $86.50 \pm 1.15 \mathrm{ab}$ & $100 \pm 0.00$ & $100 \pm 0.00$ & $100 \pm 0.00$ & 0.00 \\
S $(\%)^{*}$ & $100 \pm 0.00$ & &
\end{tabular}

IAW = initial average weight; FAWG = final average weight gain; SGR = specific growth rate; TAFI= total apparent feed intake; $\mathrm{AFC}=$ apparent feed conversion; $\mathrm{CY}=$ carcass yield; $\mathrm{S}=$ survival

*Mean values followed by the same letter in the row do not differ according to the Tukey test $(\mathrm{P}>0.05)$.

** Values on a natural-matter basis. 
The peeled-mango waste meal without seed exhibited the following results for the chemical composition on a dry-matter basis: dry matter, $91.10 \%$; crude protein, $4.74 \%$; crude fiber, 4.99\%; ether extract, $6.09 \%$; mineral matter,

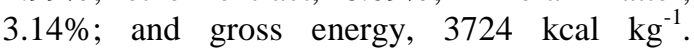
Evaluating the chemical composition of mango waste meal, but with the seed and skin, Vieira et al. (2008) found similar results to the meal evaluated in the present study for dry matter (92.2\%), crude protein $(3.9 \%)$, crude fiber $(14.6 \%)$, ether extract $(4.4 \%)$ and mineral matter $(2.1 \%)$. However, they found different values for crude fiber, due to the inclusion of the mango seed and skin, which might have affected the nutritional values.

Lower final average weight gain was observed on the animals fed the $\mathrm{CP}: \mathrm{CH}$ ratio of 0.29 , in a diet containing $50 \%$ of mango meal as source of carbohydrate. Low concentrations of mango meal seem to be more efficient in the performance of the pacamã. Lima et al. (2011) included levels $0,5,10$ and $15 \%$ mango waste meal in diets for trout and did not observe significant differences in weight gain. Melo et al. (2012) evaluated the inclusion of peeled-mango waste meal replacing corn and concluded that substitution of $100 \%$ of corn by mango does not impair the tilapia performance. According to Hilton et al. (1987), a tolerable level of carbohydrate in diets for fish is a level which does not compromise growth or results in increased mortality, whereas an optimal carbohydrate level in diets for fish is what enables glucose to be totally oxidized to produce energy, and thereby spare protein for the use of its energy in muscle growth.

For the total apparent feed intake (TAFI) of each treatment, intake was observed to increase along with the protein concentration of the diet, and consequently with the $\mathrm{CP}: \mathrm{CH}$ ratio. There were no significant differences between the ratios of $0.94,0.56$ and 0.29 , but they presented lower results than the $1.40 \mathrm{CP}: \mathrm{CH}$. Aksnes (1995) verified that feed intake decreased as the carbohydrate level of the diet for Atlantic salmon was elevated, which corroborates the results of the present study, indicating that the energy from the carbohydrate more readily available in the diet might have influenced the satiety of carnivore fish, limiting their appetite. Sampaio et al. (2000) obtained results for feed intake that followed the same trend, and the higher TAFI followed the higher CP levels of the diet.

Regarding the apparent feed conversion (AFC) of the protein:carbohydrate ratios, it was observed that 1.40 , as well as other parameters studied in this experiment, was the one to present the best result, whereas 0.56 and 0.29 provided the worst performances. Teixeira et al. (2009) found similar results to those of the present study, with the highest CP level $(57.63 \%)$ and a $\mathrm{CP}: \mathrm{CH}$ ratio of 2.13, achieving an AFC of 1.03, also verifying exponential improvement of this important animal-performance parameter as the studied ratio was increased. Sampaio et al. (2000) found at the highest CP:CH studied, 1.58, the best result (1.20) for AFC, and corroborating the present study, they verified that as this ratio was elevated, AFC improved. Although carbohydrate is largely used as a source of energy in diets for domestic animals, some fish seem to have lower ability to utilize it. Several possibilities have been discussed to explain the mechanism of fish intolerance to carbohydrates. It is also suggested that omnivore fish are capable of utilizing higher carbohydrate concentrations in the diet than the carnivores, due to the greater activity of amylase in the digestive tract (Hidalgo et al., 1999). Therefore, the ability to use different forms of carbohydrate varies according to the species.

Increasing values were found for SGR, as the $\mathrm{CP}: \mathrm{CH}$ ratios are elevated, atthe ratio of 1.40 , which caused an SGR of 0.96 , whereas the ratio of 0.29 caused an SGR of 0.01, clearly demonstrating the significant differences between the treatments. Sánchez et al. (2009) studied the influences of the protein levels (28, 32 and $36 \%$ ) on the growth of catfish (Leiarius marmoratus) fingerlings and did not find statistical difference between the treatments, unlike the results obtained herein. Teixeira et al. (2009) used diets with different protein levels for golden dorado (Salminus brasiliensis) fingerlings weighing $0.75 \mathrm{~g}$ for 29 days and found similar results to those obtained in the present study, with the highest level of $\mathrm{CP}$ of $57.63 \%$ and a $\mathrm{CP}: \mathrm{CH}$ ratio of 2.13, having an SGR of 2.8.

For carcass yield (CY), the $\mathrm{CP}: \mathrm{CH}$ ratio of 1.40 showed similar statistical result to the ratio of 0.29 , differing from the 0.56 , which displayed the worst result, although this rate increased as 
the ratio was elevated in absolute values. The best yield was obtained with the ratio containing the lowest value for the $\mathrm{CP}: \mathrm{CH}$ ratios, which occurred due to the mobilization of the energy reserves from visceral fat, decreasing the proportion between viscera and carcass. Reidel (2007) observed non-significant differences with increase in $\mathrm{CP}$ for carcass yield, which disagrees with our results. Burkert et al. (2008) worked with the processing yield of Pseudoplatystoma sp. fillets, testing three types of diet with variation in $\mathrm{CP}$ and did not observe differences between the treatments.

Survival was not affected by the different $\mathrm{CP}: \mathrm{CH}$ ratios $(\mathrm{P}>0.05)$. The elevated survival rates indicate that the diets containing mango meal as a carbohydrate source did not have a harmful effect on the health of fish. The survival rate in this study was $100 \%$, corroborating the studies of Azaza et al. (2008), who observed significant difference in the survival rate of animals fed increasing levels of date meal in contrast to decreasing soybean levels in diets for tilapia.

These values show that the efficiency of mango waste meal as a carbohydrate source in diets depends on the species and its eating habits. In a study conducted by Aksnes (1995) with the carnivore Atlantic salmon, Salmo salar L., increasing levels of carbohydrates were tested in substitution of protein in the animal diets, utilizing the $\mathrm{CP}: \mathrm{CH}$ ratios of $25.08,5.31,2.75$ and 1.66. The author obtained highest growth with the ratio of 5.3, which was much higher than that used in our study with pacamã. Figueiredo (2011) evaluated different CP:CH ratios utilizing corn meal as a carbohydrate source for pacamã juveniles and verified better performance results, as well as other parameters studied in this experiment, for the highest $\mathrm{CP}: \mathrm{CH}$ ratio of 1.24 .

The carcass chemical composition values were changed $(\mathrm{P}<0.05)$, except for mineral matter (Tab. 3). Crude protein and ether extract were lower in the diet with a $\mathrm{CP}: \mathrm{CH}$ ratio of 0.29 . The literature has few reports of the types of carbohydrates and the chemical composition of fish meat; most of them are related to energy, protein and lipid in the diet.

Table 3. Mean values plus standard deviation of the carcass characteristics of pacamã juveniles fed different $\mathrm{CP}: \mathrm{CH}$ ratios.

\begin{tabular}{lccccc}
\hline $\begin{array}{c}\text { Physicochemical } \\
\text { carcass }\end{array}$ & \multicolumn{5}{c}{$\mathrm{CP}: \mathrm{CH}$ ratios } \\
\cline { 2 - 6 } composition** & 1.40 & 0.94 & 0.56 & 0.29 & $\mathrm{CV}$ \\
$\mathrm{M}^{*}\left(\mathrm{~g} .100 \mathrm{~g}^{-1}\right)$ & $76.78 \pm 1.15$ & $76.63 \pm 2.01$ & $76.71 \pm 1.74$ & $77.01 \pm 1.65$ & 1.78 \\
$\mathrm{pH}^{*}$ & $6.0 \pm 0.10$ & $6.1 \pm 0.30$ & $6.0 \pm 0.20$ & $6.2 \pm 0.10$ & 0.90 \\
$\mathrm{CP}(\%)$ & $61.79 \pm 0.63 \mathrm{a}$ & $59.94 \pm 0.58 \mathrm{a}$ & $51.36 \pm 0.78 \mathrm{a}$ & $47.96 \pm 0.57 \mathrm{~b}$ & 7.53 \\
$\mathrm{EE}(\%)$ & $26.78 \pm 0.36 \mathrm{a}$ & $23.56 \pm 0.39 \mathrm{a}$ & $22.74 \pm 073 \mathrm{a}$ & $17.87 \pm 0.86 \mathrm{~b}$ & 6.87 \\
$\mathrm{MM}^{*}(\%)$ & $12.13 \pm 0.04$ & $15.74 \pm 0.07$ & $14.87 \pm 0.63$ & $17.10 \pm 1.74$ & 9.74 \\
\hline
\end{tabular}

$\mathrm{M}=$ moisture; $\mathrm{pH}$ - potential hydrogen; $\mathrm{CP}=$ crude protein; $\mathrm{EE}=$ ether extract; $\mathrm{MM}=$ mineral matter.

*Mean values followed by the same letter in the row do not differ according to the Tukey test $(\mathrm{P}>0.05)$.

** Values on a natural-matter basis.

The diet with a CP:CH ratio of 0.29 contained $16.24 \% \mathrm{CP}$, in which there was a deficit for this nutrient, according to the requirements for this species (National..., 2011), and this reduced the protein synthesis and ether extract in the carcass of the animals.

Signor et al. (2007) did not observe significant differences for crude protein, ether extract and mineral matter in the carcass when they used poultry offal meal in the feeding of Leporinus macrocephalus.
The concentrations of carbohydrates in the diet modify the chemical profile of pacamã meat. In trout meat they reduced the fat and energy and increased protein, and ash contents were elevated with higher carbohydrate (Veiverberg et al., 2010). Fabregat et al. (2011) evaluated substitution of fish meal by soybean meal in the diet and verified reduction in the crude protein contents of the carcass of Prochilodus lineatus juveniles.

The Brazilian legislation considers that fish whose external-meat $\mathrm{pH}$ is above or equal 6.8 , or 
whose internal-meat pHi s above or equal 6.5, are unsuitable for consumption (Brasil, 1997). The $\mathrm{pH}$ values remained within the Brazilian norms for commercialization and consumption; the different $\mathrm{CP}: \mathrm{CH}$ ratios did not affect the $\mathrm{pH}$ of the pacamã meat.

The chemical composition of the carcass is reflected by the nutrients in the diet, and so their imbalance may affect it.

\section{CONCLUSIONS}

Increase in the $\mathrm{CP}: \mathrm{CH}$ ratio improves performance of pacamã fish. The $\mathrm{CP}: \mathrm{CH}$ ratio of 0.29 reduces the protein and lipid deposition in the carcass. Among the ratios studied in this experiment, the $\mathrm{CP}: \mathrm{CH}$ ratio of 1.40 is recommended for the best performance of pacamã; however, higher ratios may be tested to verify their effectiveness. Pacamã has desirable animal performance characteristics for commercial cultivation.

\section{REFERENCES}

AKSNES, A. Growth, feed efficiency and slaughter quality of salmon, Salmosalar L., given feeds with different ratios of carbohydrate and protein. Aqua. Nut., v.1, p.241-248, 1995.

ANDRIGUETTO, J.M.; PERLY, L.; MINARDI, I. et al. Nut. Ani. 4.ed. São Paulo: Nobel, v.4, p.71-79, 1985.

ARGAIZ, A.; VERGARA, F.; WELTI, J. et al. Durazano conservado por factores combinados. CYTED. Bol. Intern. Divulg., v.1, p.22-30, 1993.

AZAZA, M.S.; MENSI, F.; KAMMOUN, W. et al. Nutritional Evaluation of Waste Date Fruit as Partial Substitute for Soybean Meal in Practical Diets of Juvenile Nile Tilapia, Oreochromisniloticus L. Aqua. Nut., v.15, p.262-272, 2008.

BOYD, C.E. Water Quality in Ponds for Aquaculture. Alabama Agricultural Experimente Station. Alabama:Auburn University, 1990. p. 482.

BRASIL. Ministério da Agricultura. Secretaria Nacional de Defesa Agropecuária. Laboratório Nacional de Referência Animal (LANARA). Métodos físicos e químicos. LANARA, Brasília, DF. p. 123, 1981. Disponível em: < http://www.agricultura.gov.br/ arq_editor/file/Aniamal/Laborat\%C3\%B3rios/labMIC ROBIAL.pdf >. Acessado em 17 out. 2012.
BRASIL. Ministério da Agricultura Pecuária e Abastecimento. Regulamento da Inspeção Industrial e Sanitária de Produtos de Origem Animal R.I.I.S.P.O.A. Diário Oficial da República Federativa do Brasil, Brasília, DF, 1997. Disponível em: <http://www.agricultura. gov.br/arq_editor/file/ Aniamal/MercadoInterno/Requisitos/RegulamentoInsp ecaoIndustrial.pdf > . Acessado em 18 out. 2012.

BURKERT, D.; ANDRADE, D.R.; SIROL, R.N. et al. Rendimentos do processamento e composição química de filés de surubim cultivado em tanques-rede. Rev. Bras. Zootec., v.37, p.1137-1143, 2008.

COELHO, E.P.; OLIVEIRA, F.C.; NASCIMENTO, C.J.A. et al. A cultura da manga sob diferentes regimes de profundidades do lençol freático em condições subúmidas. Rev. Bras. Frut., v.24, p.96-100, 2002 .

FABREGAT, T.E.H.P.; PEREIRA, T.S.; BOSCOLO, C.N. et al. Substituição da farinha de peixe pelo farelo de soja em dietas para juvenis de curimba. Bol. Inst. Pesc., v.37, p.289-294, 2011.

FIGUEIREDO, R.A.C.R. Avaliação da relação proteína:carboidrato na dieta de juvenis de Pacamã, LophiosilurusalexandriSteindachner, 1877 (Pisces:Siluriformes). 68p. 2011. Dissertação (Mestrado em Ciência Animal) - Universidade Federal do Vale do São Francisco.

HIDALGO, M.C.; UREA, E.; SANZ, A. Comparative study of digestive enzymes in fish with nutritional habits. Proteolytic and amylase activities. Aqua., v.170, p.267-283, 1999.

HILTON, J.W.; PLISETSKAYA, E.M.; LEATHERLAND, J.F. Does oral 3,5,3'- triiodo-Lthyronine affect dietary glucose utilization and plasma insulin levels in rainbowtrout (Salmogairdneri). Fish. Phy. and Bioche., v.4, p.113-120, 1987.

KAUSHIK, S.J. Use of alternative protein sources for intensive rearing of carnivorous fishes. In: SHIAU, S.Y. (Ed). Prog. in Fish. Nut. Taiwan : ROC., 1989. p.181-208.

KUBITZA, F. Nutrição e Alimentação de Peixes Cultivados. 1.ed. Campo Grande, 1998. 44p.

LIMA, M.R.; LUDKE, M.C.M.M.; PORTO-NETO, F.F. et al. Farelo de resíduo de manga para tilápia do Nilo. Act. Scient.,v.33, p.65-71, 2011.

MELO, J.F.B.; SEABRA, A.G.L.; SOUZA, A.S. et al. Substituição do farelo de milho pela farinha de manga no desempenho da tilápia-do-nilo. Arq. Bras. Med. Vet. Zoot., v.64, p.177-182, 2012. 
MONTEIRO, B.A. Valor nutricional de partes convencionais e não convencionais de frutas $e$ hortaliças. 62p. 2009. Dissertação (Mestrado em Energia na Agricultura) - Universidade Estadual Paulista - Júlio de Mesquita Filho.

NATIONAL Research Council -NRC. Nutrient requirement of fish and shrimp. Washingtown: National Academic Press, 2011. p.164 -184.

OFFICIAL methods of analysis - AOAC. Ass. Off. Ana. Che. 15.ed. Washington. p.1018, 1990.

REIDEL, A. Níveis de energia e proteína na alimentação do jundiá (Rhamdiaquelen) criados em tanques-rede. 85f. 2007. Tese Doutorado (Pósgraduação em Aquicultura), Universidade Estadual Paulista - Jaboticabal - Centro de Aquicultura da Unesp.

SAMPAIO, A.M.B.M.; KUBITZA, F.; CYRINO, J.E.P. Relação proteína: energia na nutrição do tucunaré. Scien. Agri., v.52, p.213-219, 2000.

SÁNCHEZ, J.A.M.; MOYETONES, F.; CERDÁ, M.J. Influencia delcontenido proteico enelcrecimiento de alevines de bagre yaque, Leiariusmarmoratus, alimentados con concentrados comerciales. Zootec. Trop., v.27, p.187-194, 2009.

SHIBATA, O.A. Family Pseudopimelodidae. In: REIS, R.E.; KULLANDER, S.O.; FERRARIS, J.C.J. Check list of the freshwater fishes of South and Central America. Edip., v.1, p.401-405, 2003.
SIGNOR, A.A.; BOSCOLO, W.R.; FEIDEN, A. et al. Farinha de vísceras de aves na alimentação de alevinos de piavuçu (Leporinusmacrocephalus). Cienc. Rural, v.37, p.828-834, 2007.

SILVA, F.A.S. Assistat Versão 7.5 Beta. 2010. Disponível em: <http://www.assistat.com.br/ .htm>. Acessado em 17 Out. 2012.

SILVEIRA, U.S.; LOGATO, P.V.R.; PONTES, E.C. Utilização e metabolismo dos carboidratos em peixes. Rev. Ele. Nut., v.6, p.817-836, 2010.

TEIXEIRA, B.; MACHADO, C.; FRACALOSSI, D. Exigência protéica em dietas para alevinos do dourado (Salminus brasiliensis). Act. Scient. Anim. Sci., v.32, p.73-87, 2009.

VEIVERBERG, C.A.; RADÜNZ NETO, J.; SILVA, J.L.P. et al. Teores de proteína bruta em dietas práticas para juvenis de carpa capim. Arq. Bra. Med. Vet. Zootec., v.62, p.1241-1249, 2010.

VIEIRA, P.A.F.; QUEIROZ, J.H.; ALBINO, L.F.T. et al. Efeitos da inclusão de farelo de resíduo de manga no desempenho de frangos de corte de 1 a 42 dias. Rev. Bras. Zootec., v.37, p.2173-2178, 2008. 